\title{
Epistemic Democracy and International Students
}

\author{
Aneta Hayes \\ Keele University, United Kingdom
}

In this 10th anniversary essay, I would like to address the topic I have been writing about for quite a while now-namely, how to create conditions for epistemic democracy for international students attending our universities. By "epistemic democracy" I mean not being silenced and "wronged" as knowers through teaching experiences that prevent any distortion and discreditation of particular intellectual traditions. I believe this topic is important because, despite institutional announcements that commit universities to building on the strengths that come from the diversity of internationalization of higher education, the problem of intellectual subordination of international students in university classrooms has still not been adequately addressed.

In my recent monograph Inclusion, Epistemic Democracy and International Students: The Teaching Excellence Framework and Education Policy, I have argued that the intellectual benefits of learning alongside international students are insufficiently appreciated. This is because educational policies, which for many years have represented international students as "foreigners" who benefit from Western education systems, socialize university staff and home students into the view that these "foreigners" are intellectually inferior. Home students therefore, on their own and without the help of their institutions, lack agency to engage with international students on epistemologically equal terms. But how can these home students be expected to deal with the lack of epistemic democracy on their own, if the limitations of the policies that govern their education systems, especially those that constitute official university rankings, do not establish any obligation for universities to engage with international people on more reciprocal terms?

They can't because when the problem is systemic, it needs to be addressed by a change in the system. This change needs to socialize universities into new interdependencies with international students. That is why I argue in my work that we need a "ranking" that will afford knowledge production to all people (as nowadays what is not measured, does not happen); one that will lead to epistemic democracythat is, a situation whereby universities collectively work toward fighting coloniality 
in internationalization (i.e., intellectual, social, and political domination over international students in an education system).

People have often asked me: "How could such a ranking work?" Well, in my work I have specifically undertaken data modeling of some sample national data in the United Kingdom to answer this question. I have shown sample analytical models that conceptualize and show in practice steps toward a critical pedagogy of internationalization (i.e., how to measure the type of the education process that is guided by teaching standards that facilitate knowledge production that is equal, just, and free from coloniality participation). I have shown that it is possible, through specific data modeling, to capture the extent to which intellectual reciprocity is invited by university tutors, as the analyses that I have proposed measure the relationalities between inclusive characteristics of the teaching process and realization of students as epistemic equals.

There are of course some limitations of the analysis I have used, which will probably annoy many statisticians. But they can be addressed and are no greater than the caveats that characterize the current nature and scope of many university rankings. The most important thing, however, is that through the analyses I discuss, we can actually measure the type of pedagogical intentionality that can lead to intellectual transformations in university seminar rooms. By nature, such intentionality is a relative concept, which means that we can measure how each university performs to their own specification (and consequently will be able to take account of any changes to these specifications when they occur).

There are therefore no absolutes against which the output can be assessed, nor are there any universal benchmarks. This is the most significant difference that distinguishes the proposed "ranking for epistemic democracy" from the existing ones. The absence of such benchmarks makes the proposed ranking apolitical as the analysis of data is focused purely on the educational process that underlies intellectual inclusion of all students. As such, the ranking can be distanced from any national selfinterests that we know are often associated with internationalization, and can also prevent further politicization of international students. Instead, the universities can focus on assessing one core idea - that is, how and to what extent international students' rights to knowledge production are actually shaped and enacted on the ground in our universities.

ANETA HAYES, $\mathrm{PhD}$, is a senior lecturer in Education at Keele University. Her research interests include critical policy analysis, internationalization, and higher education developments around the world. She has recently authored a book Inclusion, Epistemic Democracy and International Students: The Teaching Excellence Framework and Education Policy. Email: a.m.hayes@keele.ac.uk 